\title{
Choledocystus elegans (Digenea: Plagiorchiidae) of Leptodactylus paraensis (Amphibia: Leptodactylidae) from the Brazilian Amazon
}

\author{
Choledocystus elegans (Digenea: Plagiorchiidae) de Leptodactylus paraensis (Amphibia: Leptodactylidae) da \\ Amazônia brasileira
}

Tássia Fernanda Furo Gomes ${ }^{1 *}$; Francisco Tiago de Vasconcelos Melo할 Elane Guerreiro Giese²;

Adriano Penha Furtado ${ }^{1}$; Jeannie Nascimento dos Santos ${ }^{1}$

\begin{abstract}
${ }^{1}$ Laboratório de Biologia Celular e Helmintologia "Profa. Dra. Reinalda Marisa Lanfredi, Instituto de Ciências Biológicas, Universidade Federal do Pará - UFPA, Belém, PA, Brasil

${ }^{2}$ Laboratório de Histologia e Embriologia Animal, Instituto de Saúde e Produçăo Animal, Universidade Federal Rural da Amazônia UFRA, Belém, PA, Brasil
\end{abstract}

Received June 4, 2017

Accepted August 3, 2017

\begin{abstract}
The trematodes are parasites of the several vertebrates including amphibians, however the knowledge about of the taxonomy these parasites is still confuse. The trematode Choledocystus elegans was found in the small intestine of the Leptodactylus paraensis in eastern Amazon and presents the following characteristics: several pointed tegumentary spines, papillae on the outer and inner edges of the oral and ventral suckers, a round, well-developed cirrus sac, a well-developed cirrus, oblique testicles, a ovary right side, uterine loops extending between the testicles, follicular vitellaria distributed throughout the body, starting at the genital pore region and caeca close the end of the body. For the first time, this study identified C. elegans parasitizing L. paraensis and describes morphological aspects never characterized using light and scanning electron microscopy.
\end{abstract}

Keywords: Leptodactylus paraensis, Trematode, Choledocystus elegans, Amazon.

\section{Resumo}

Os trematodas são parasitas de vários grupos de vertebrados incluindo os anfíbios, contudo o que se conhece sobre a taxonomia destes parasitas ainda é confusa. O trematoda Choledocystus elegans foi encontrado no intestino delgado de Leptodactylus paraensis na Amazônia oriental e apresenta as seguintes características: vários espinhos pontiagudos no tegumento, papilas nas bordas externa e interna das ventosas orais e ventrais, bolsa do cirro bem desenvolvida contendo um cirro desenvolvido, testículos oblíquos, ovário destro, alças uterinas que se estendem entre os testículos, folículos vitelínicos distribuída por toda a lateral do corpo, começando ao nível do poro genital e cecos intestinais chegando até a região posterior do corpo do helminto. Pela primeira vez, este estudo identificou C. elegans parasitando L. paraensis e descreve aspectos morfológicos nunca caracterizados usando microscopia de luz comum e eletrônica de varredura.

Palavras-chave: Leptodactylus paraensis, Trematoda, Choledocystus elegans, Amazônia.

Leptodactylus paraensis Heyer, 2005 is popularly known as the Pará thin-toed frog and can be found in eastern Amazon, from the state of Pará to northern state of Mato Grosso, Brazil. This amphibian has a terrestrial habitat and is found in both the wild and the peridomicile urban environment (HEYER, 2005; SILVANO \& SEGALLA, 2005).

The genus Choledocystus Pereira \& Cuocolo, 1941 was established to determine the species Choledocystus eucharis Pereira

${ }^{*}$ Corresponding author: Tássia Fernanda Furo Gomes. Laboratório de Biologia Celular e Helmintologia "Profa. Dra. Reinalda Marisa Lanfredi", Instituto de Ciências Biológicas, Universidade Federal do Pará - UFPA, Av. Augusto Corrêa, s/n, CEP 66075-110, Belém, PA, Brasil. e-mail: tassiagomes@ufpa.br
\& Cuocolo, 1941 in Brazil, a Trematoda e of the bile ducts of Leptodactylus ocellatus Linnaeus, 1758, is composed by liver, gall blader and bile ducts parasites of amphibian of distribution in South America (RAZO-MENDIVIL \& PÉREZ-PONCE DE LEÓN, 2008; TKACH, 2008). The characteristics that considered Choledocystus as valid genus in family Plagiorchiidae: the presence of a sucker-like structure surrounding the genital atrium, absence of a seminal receptacle and the shape of uterine loops along the body (RAZO-MENDIVIL \& PÉREZ-PONCE DE LEÓN, 2008; TKACH, 2008).

The genus Leptodactylus is the host of some species of helminth parasites, such as Digenea, including parasites of the genus 
Choledocystus, very similar to genus Glypthelmins Stafford, 1905 (Glypthelminthidae). These parasites are common to several other amphibian species from the Americas, such as hosts of the genera Rana (= Lithobates) Linnaeus, 1758; Pseudacris (= Hyla) Fitzinger, 1843; Rhinella (= Bufo) Fitzinger, 1826 and Leptodactylus Fitzinger, 1826, which belong to the order Anura, and the genus Chthonerpeton Peters, 1880, which belongs to the order Gimnophiona (RANKIN, 1944; DOBBIN, 1958; TRAVASSOS et al., 1969; RAZO-MENDIVIL \& PÉREZ-PONCE DE LEÓN, 2011; GOMES et al., 2013; FERNANDES \& KOHN, 2014; KUZMIN et al., 2016). Until now, there is no report of trematodes parasites from $L$. paraensis, the present study describes new host, new geographical occurrence and infection site of parasitism of Choledocystus elegans (Travassos, 1926) Ruiz \& Leão (1942) and news morphological aspects for this species.

Four specimens of $L$. paraensis were collected in peridomicile areas (01'28'03”S, 48²0'18'W) in the municipality of Belém, state of Pará, eastern Amazon (Brazil). The collected specimens were taken to the Laboratory of Cell Biology and Helminthology "Profa. Dra. Reinalda Marisa Lanfredi" of the Institute of Biological Sciences located at the Federal University of Pará (UFPA), anesthetised and euthanised with sodium thiopental. Digestive tubes were isolated in phosphate-saline buffer (PBS) ( $\mathrm{pH} 7.4$ ), and the presence of helminths was evaluated.

Light microscopy analysis were proceed from 10 specimens (one holotype and nine vouchers). The trematodes were fixed under coverslip pressure with AFA (2\% glacial acetic acid, 3\% formaldehyde and $95 \%$ ethanol $70^{\circ} \mathrm{GL}$ ), stained chloridric carmine, dehydrated in a graded alcohol series and clarified with methyl salicylate (GIESE et al., 2015). The morphometric data were obtained with the aid of an Olympus BX 41 microscope attached to a drawing tube and the measurements are in millimetres, otherwise stated and are shown as: the mean \pm standard deviation the mean + standard deviation followed by range in parenthesis.

Scanning electron microscopy, were proceed from 10 specimens were fixed in AFA, post-fixed in $1 \% \mathrm{OsO}_{4}$, dried at the critical point of $\mathrm{CO}_{2}$, coated with gold and observed in SEM LEO-1450 microscope of the Laboratory of Electron Microscopy at the Institute of Geosciences of UFPA (GIESE et al., 2015).

\section{Choledocystus elegans (Travassos, 1926) Ruiz, 1949 (Description Based/ Lower Case on 10 Vouchers: Using Light and Scanning Electron Microscopy)}

Body elongated $2.77 \pm 0.68(1.73-3.86) \times 0.87 \pm 0.13$ (0.62 - 1.10); ratio body width/body length $1: 3$ (Figures 1 and $2 a$ ). Tegument covered with triangular spines (Figures $3 \mathrm{a}, \mathrm{b})$. Oral sucker subterminal, rounded, ventral $0.22 \pm 0.03(0.18-0.31) \times 0.23 \pm 0.02$ $(0.20-0.27)$ and surrounded by an elevation of the tegument at the anterior end (Figures 1 and $2 \mathrm{a}, \mathrm{b}$ ). Papillae distributed on the internal contour of the oral sucker with the following pattern: three pairs of papillae juxtaposed in the apical region and two pairs of lateral papillae (Figure 2b). Papillae of the outer edge of the oral sucker with the following pattern: three pairs of papillae juxtaposed on the anterior edge of the opening and four pairs of papillae lining the perimeter of the oral sucker (Figures $1 \mathrm{~b}$ and $2 \mathrm{~b}$ and $\mathrm{c}$ ). Six tegumental papillae below the oral sucker, round and small (Figure 2b). Prepharynx present (Figures 1a, b).

Medial glands located around the pharynx and oesophagus (Figures 1a, b). Pharynx globular developed $0.14 \pm 0.03$ $(0.08-0.19) \times 0.15 \pm 0.02(0.13-0.20)$ (Figures $1 \mathrm{a}, \mathrm{b})$ Oesophagus long $0.20 \pm 0.09(0.09-0.36) \times 0.10 \pm 0.02$ (0.07-0.14) (Figures 1a, b). Long, narrow, slightly asymmetric intestinal caecum, $2.09 \pm 0.51(1.16-2.94)$ right caecum and $2.09 \pm 0.56(1.11-2.96)$ left caecum (Figure 1a). Genital pore surrounding with sucker-like structure, destral-medial, anterior to the ventral sucker (Figures 1, 2a and 3c, d). Well-developed cirrus, covered with small spines (Figures 1, 2a and 3c, d). Voluminous, sinistral, curved cirrus sac above the ventral sucker $0.52 \pm 0.11$

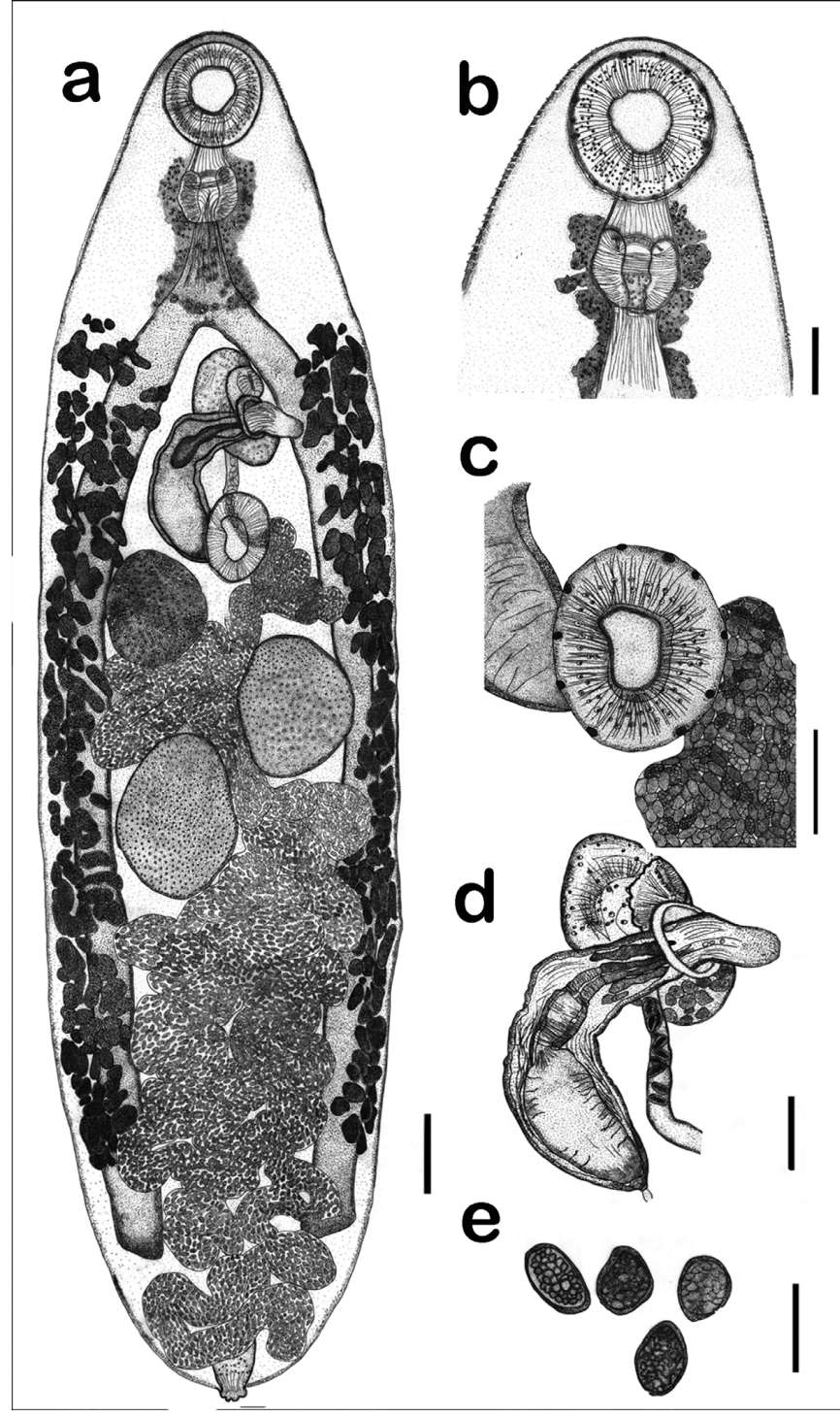

Figure 1. Line drawings obtained from light microscopy of Choledocystus elegans: (a) general view of the whole worm. Bar $=200 \mu \mathrm{m}$; (b, c) Details of the oral sucker and ventral sucker. Bar $=100 \mu \mathrm{m}$; (d) Cirrus, genital pore aperture, cirrus sac and metraterm. Bar $=100 \mu \mathrm{m}$. (e) Eggs. Bar $=30 \mu \mathrm{m}$. 
$(0.39-0.7) \times 0.10 \pm 0.01(0.08-0.14)$, prostatic glands numerous, surrounding the cirrus and bipartite seminal vesicle (Figures 1a-d).

Round ventral sucker with small papillae on its outer edge, located in the parasite anterior third $0.22 \pm 0.04(0.17-0.32) \times 0.21 \pm 0.03$ (0.17 - 0.27) (Figures 1 and 2a). Oral sucker/ventral sucker ratio 1:1. Five pairs of papillae in the outer perimeter of the ventral sucker (Figures $1 \mathrm{c}$ and 2d). Two pairs of internal papillae in the ventral sucker (Figure 2e). Round ovary located between the ventral

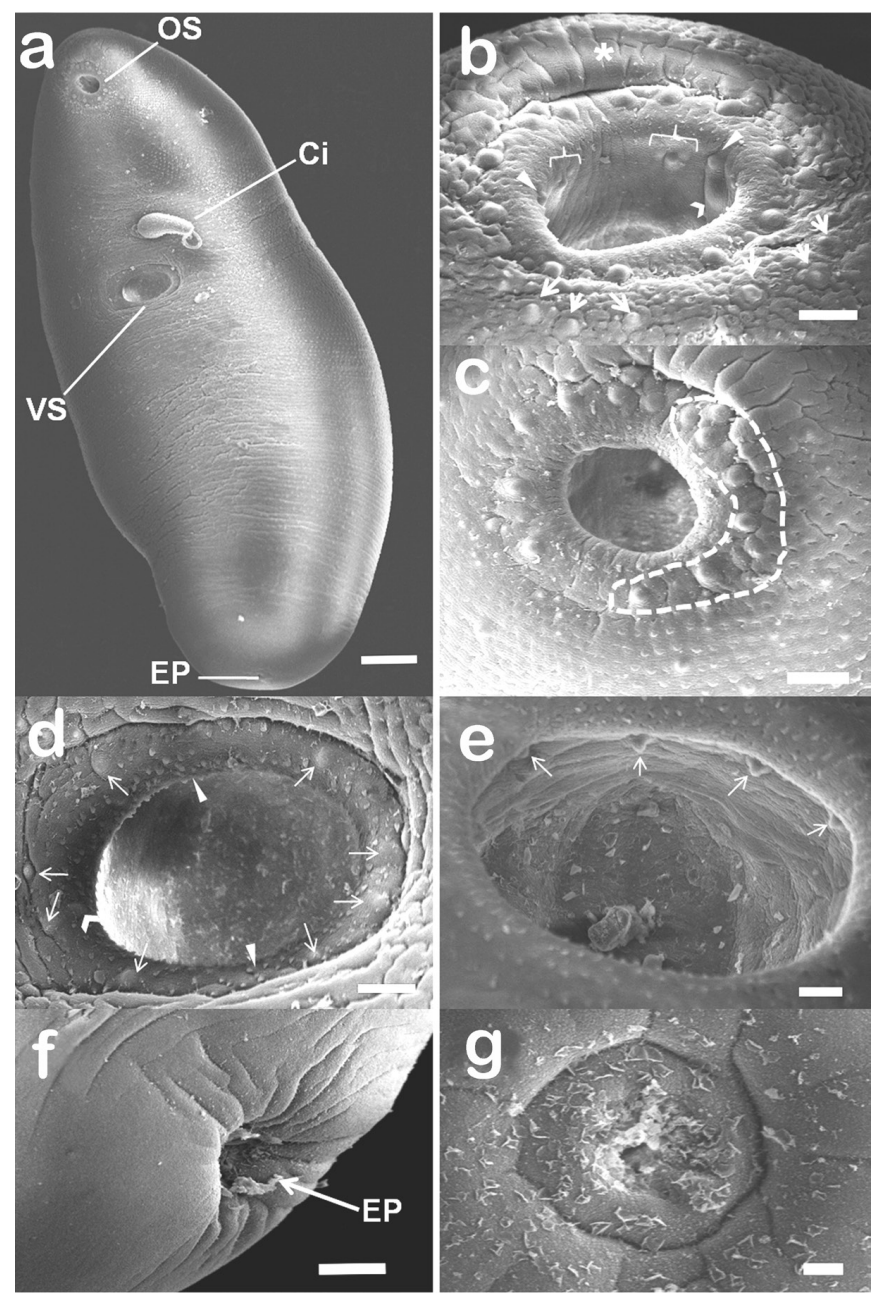

Figure 2. Scanning electron micrographs of Choledocystus elegans: (a) General view of the trematode ventral surface. Oral sucker (OS), everted cirrus (Ci), lightly concave ventral sucker. (VS) and excretory pore $(\mathrm{EP})$. Bar $=100 \mu \mathrm{m}$; (b) Oral sucker, showing the apical elevation of the tegument $\left({ }^{*}\right)$ at the anterior border of the sucker and the internal distribution of papillae: two groups of three adjacent papillae (keys) and two lateral (arrowhead); in the tegument below oral sucker, are observed six papillae divided into two groups of three (arrows). Bar $=20 \mu \mathrm{m}$; (c) Details of the oral sucker, showing six pairs of small rounded (dotted line). Bar $=20 \mu \mathrm{m}$; (d) Detail of the ventral sucker outlined by papillae distributed around the perimeter of the opening (arrows), interspersed with a large number of spines (arrowhead). Bar $=20 \mu \mathrm{m}$; (e) In the inner region of the ventral sucker, two pairs of domed papillae were observed (arrows). Bar $=10 \mu \mathrm{m}$; (f, g) Detail of the terminal excretory pore (EP) showing its spherical aperture, lack of spines or papillae and the presence of little pleats. Bar $=20 \mu \mathrm{m}$ and $4 \mu \mathrm{m}$, respectively. sucker and the right testicle $0.28 \pm 0.06(0.15-0.36) \times 0.22 \pm 0.04$ (0.14-0.28) (Figure 1a). Intercaecal, round, oblique testicles, below the ventral sucker $0.29 \pm 0.07(0.18-0.42) \times 0.25 \pm 0.05$ $(0.14-0.33)$, the right testicle $0.26 \pm 0.06(0.16-0.36) \times 0.27 \pm 0.05$ (0.16-0.35) and the left testicle (Figure 1a). Absence of a seminal receptacle. Laurer's canal and Mehlis' gland present.

Vitellaria distributed in the extracaecal and caecal region, follicular, starting before the genital pore extending up to half of the posterior third and just before the end of the caecum (Figure 1a). Uterine loops distributed in the intercaecal and caecal regions, descendent to the genital pore and then ascendant, ending in a well-developed metraterm that open at the atrium (Figures $1 \mathrm{a}$ and d). Eggs operculate elliptical, smooth and numerous $0.02 \pm 0.00$ $(0.02-0.027) \times 0.01 \pm 0.000(0.012-0.015)$ (Figures 1 and $3 e, f)$. "Y"-shaped excretory vesicle. Excretory pore terminal, spherical opening with the presence of pleats of varied size, lack of spines or papillae on the outer edge (Figures $1 \mathrm{a}$ and $2 \mathrm{f}, \mathrm{g}$ ).

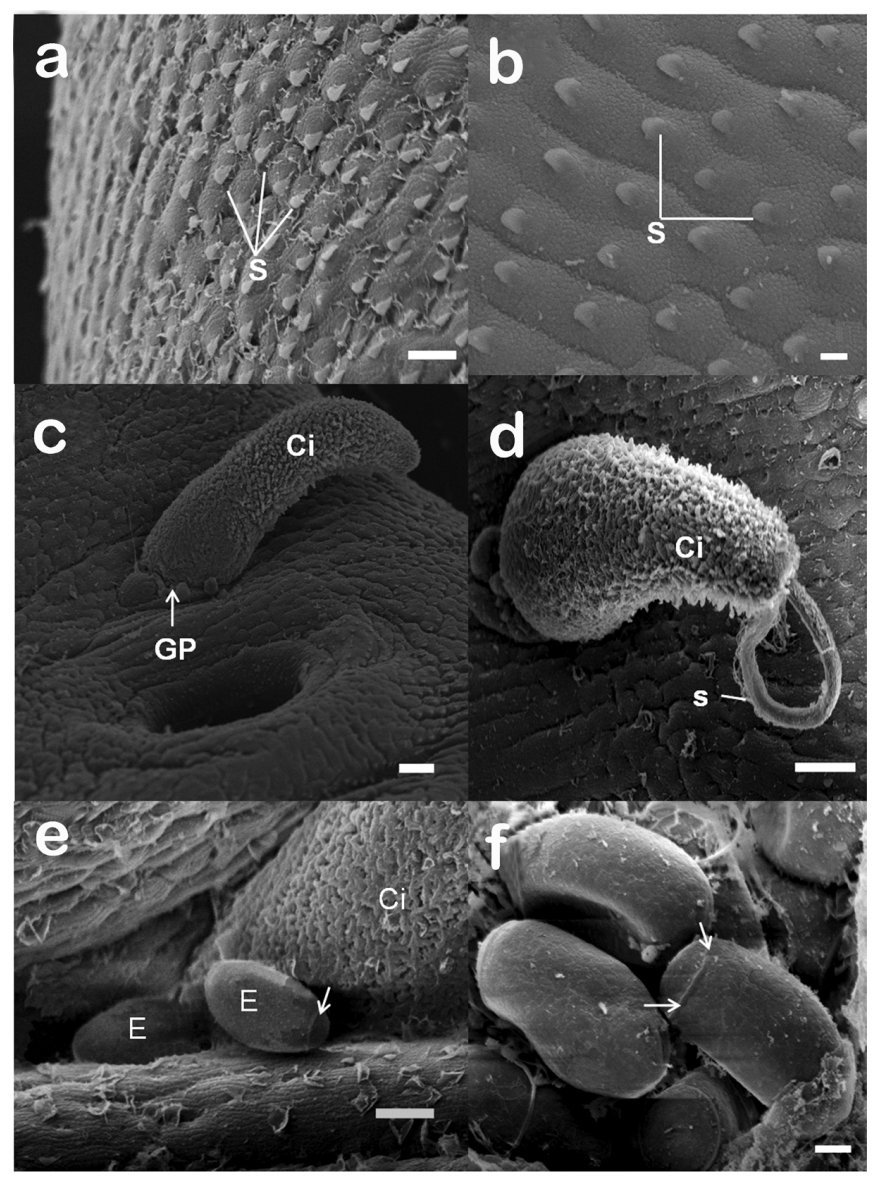

Figure 3. Scanning electron micrographs of Choledocystus elegans: (a) Detail of the ventrolateral region of the first-third of the body, showing numerous spines (S). Bar $=10 \mu \mathrm{m}$; (b) Detail of tegumentary showing showing the cuneiform shape of spines $(S)$ base and thin, delicate tip. Bar $=4 \mu \mathrm{m}$; (c, d) Detail of the genital pore (GP), showing the presence of the anterior extremity of the cirrus $(\mathrm{Ci})$ and spermatozoids $(\mathrm{S})$. Bar $=20 \mu \mathrm{m}$; (e, f) Eggs (E) located at the opening of the genital pore next to the cirrus $(\mathrm{Ci})$ and a small elevation (arrow) outlining the perimeter of the operculum. Bar $=10 \mu \mathrm{m}$ and $4 \mu \mathrm{m}$, respectively. 


\section{Taxonomic Summary}

Plagiorchiidae Luhe, 1901.

Choledocystus Pereira \& Cuocolo, 1941.

Choledocystus elegans (Travassos, 1926) Ruiz, 1949

Host: Leptodactylus paraensis Heyer, 2005 (Amphibia:

Leptodactylidae)

Site of infection: small intestine

Locality: $01^{\circ} 28^{\prime} 03^{\prime \prime}$ S, 48²0'18” W, municipality of Belém, state of Pará, Brazil.

Prevalence: 75\%; Intensity of infection: 5-20.

Deposition of specimens: Invertebrate Collection of the Emílio Goeldi Paraense Museum (Museu Paraense Emílio Goeldi - MPEG), Belém, state of Pará, Brazil. №. 20170400002 - MPEG 0114 a 0115.

The studied specimens have the following characteristics: rounded-fusiform body, tegument covered with spines, subterminal oral sucker, presence of prepharynx, developed pharynx, presence of glands around the pharynx, long caecum reaching four-fifths of body size, ventral sucker at the end of the anterior third of the helminth body, intercaecal testicles, long, curved cirrus sac, ovary anterior to testicles and below ventral sucker, intercaecal uterus, developed metraterm, operculate eggs, caecal follicular vitellaria, absence of a seminal receptacle and "Y"-shaped extracaecal and excretory vesicles, which according to Tkach (2008) and Razo-Mendivil et al. (2006) are common characteristics of the genus Choledocystus.

The morphological characteristics of the genus Choledocystus are similar to genus Glypthelmins, but is are distinguished mainly by the absence of a seminal receptacle in Choledocystus (RUIZ \& LEÃO, 1942). Razo-Mendivil et al. (2006) described other characteristics that differ the two genera, the presence of a muscular structure (sucker-like) surrounding the genital pore is characteristic of Choledocystus and absent in Glypthelmins, the tegumental spines are triangular shows typical structure of Choledocystus, in Glypthelmins the spines are serrated as per the most recent revision of the genus.

According to Razo-Mendivil \& Pérez-Ponce de León (2008) the first species of the genus Choledocystus described was C. eucharis parasitizing bile ducts of $L$. ocellatus in Brazil, later Choledocystus vesicalis Ruiz \& Leão, 1942 in gall bladder of Bufo marinus (=Rhinella marina) Linnaeus, 1758, also was described in Brazil. Choledocystus intermedius Cabalero, Bravo \& Zerecero, 1944 was found parasitizing the liver and gall bladder in $R$. marina in México. Ruiz \& Leão (1942) after analysis of Glypthelmins elegans, parasite of anurans in Brazil, proposed to include G. elegans in Choledocystus being the new nomenclature C. elegans (Travassos, 1926) Ruiz \& Leão (1942), considered C. eucharis and C. vesicalis as synonyms to $C$. elegans.

Choledocystus hepaticus Lutz, 1928, parasite of liver in $R$. marina of the Venezuela, was considered synonymous of $C$. intermedius; however, as redescribed $C$. hepaticus is a different species, considered size of the sucker ratios, egg size and position of vitellaria different from other species (SULLIVAN, 1977). Therefore, there are three species considered valid to genus Choledocystus: C. intermedius, C. hepaticus and the type-species C. elegans.
In this study was observed for the first time in L. paraensis the occurrence of parasites of the genus Choledocystus. The species C. elegans in the Brazilian Amazon, parasites of the L. paraensis. Analysis the three species by description articles of the genus Choledocystus and the keys of identification to trematodes, were important for the identification of the parasite of this study (POJMANSKA, 2008).

In this study, C. elegans was found parasitizing small intestine of $L$. paraensis, the parasites were adhered to the intestinal mucosa. The genus Choledocystus includes trematodes parasites of liver, gall bladder and bile ducts in amphibians from the North, Central and South Americas (RUIZ \& LEÃO, 1942; RAZO-MENDIVIL \& PÉREZ-PONCE DE LEÓN, 2008). Lunaschi \& Drago (2010) described the genus Choledocystus living in small intestine in Leptodactylus latrans Steffen, 1815 from the Argentina. Fernandes \& Kohn (2014) related Choledocystus parasitizing small intestine of the anurans Pseudis paradoxa Linnaeus, 1758 and R. marina from the Venezuela, Pseudis minuta Gunther, 1858 and L.latrans from the Uruguay and Hypsiboas raniceps Cope, 1862 from the Brazil. This is work are first record of C. elegans in Brazilian Amazon and site of infection small intestine in $L$. paraensis.

The ultrastructure of the tegument of $C$. elegans revealed the presence of tegumental papillae near the oral sucker and on the outer and inner edges of this sucker. Papillae on the inner edge of the ventral sucker never have been observed in C. elegans. Papillae interspersed with spines on the outer edge of the ventral sucker and tegumental papillae below the oral sucker are characteristics never described for this species. The present study is the first to illustrate the ultrastructural details of the papillae and their distribution pattern in tegument and suckers in trematodes of the genus Choledocystus, adding new characteristics to the genus.

Amphibians of the genus Leptodactylus are commonly parasitized by several groups of helminths, in $L$. paraensis the first and only record of parasite was made by Kuzmin et al. (2016) in a study who described two new species of nematodes of the genus Rhabdias Stiles et Hassall, 1905 and one of these species was parasitizing $L$. paraensis, the nematode Rhabdias stenocephala Kuzmin et al. (2016).

Thus, the present study is the second record of parasitism by helminths in L. paraensis, the first record of trematodes of the genus Choledocystus for the Brazilian Amazon and was added details of the ultrastructure of the tegument of $C$. elegans never been observed in parasites of the genus Choledocystus reinforcing characteristics inherent to the genus.

\section{Acknowledgements}

The authors are grateful to the Brazilian Graduate Training Committee (CAPES-PROCAD NF/2009), CAPES-PARASITOLOGIA BÁSICA/2010, CNPq-SISBiota/2010 and PROPESP/FADESPUFPA. The authors are grateful to Emanuele G. G. de Argolo, Jurupytan V. da Silva and Yuri Willkens de Oliveira Costa for technical support. 


\section{References}

Dobbin JE Jr. Glypthelmins vitellinophilum sp. n., parasito de Hyla raniceps (Cope): (Trematoda, Plagiorchidae). Mem Inst Oswaldo Cruz 1958; 56(1): 153-157. http://dx.doi.org/10.1590/S0074-02761958000100007.

Fernandes BMM, Kohn A. South American trematodes parasites of amphibians and reptiles. Rio de Janeiro: Oficina de Livros; 2014.

Giese EG, Silva MVO, Videira MN, Furtado AP, Matos ER, Gonçalves EC, et al. Rohdella amazonica n. sp. (Aspidogastrea: Aspidogastridae) from the Amazoninan banded puffer fish Colomesus psittacus (Bloch \& Schneider, 1801). J Helminthol 2015; 89(3): 288-293. PMid:24572176. http://dx.doi.org/10.1017/S0022149X14000054.

Gomes TFF, Melo FTV, Giese EG, Furtado AP, Gonçalves EC, Santos JN. A new species of Mesocoelium (Digenea: Mesocoeliidae) found in Rhinella marina (Amphibia: Bufonidae) from Brazilian Amazonia. Mem Inst Oswaldo Cruz 2013; 108(2): 186-191. PMid:23579798. http:// dx.doi.org/10.1590/0074-0276108022013010.

Heyer WR. Variation and taxonomic clarification of the large species of the Leptodactylus pentadactylus species group (Amphibia: Leptodactylidae) from middle America, northern south America and Amazonia. Arq Zool 2005; 37(3): 269-348. http://dx.doi.org/10.11606/issn.2176-7793. v37i3p269-348.

Kuzmin Y, Melo FTV, Silva HF Fo, Santos JN. Two new species of Rhabdias Stiles et Hassall, 1905 (Nematoda: Rhabdiasidae) from anuran amphibians in Pará, Brazil. Folia Parasitol 2016; 3: 63. PMid:27189518.

Lunaschi LI, Drago FB. Platyhelminthes, Trematoda, Digenea Carus, 1863: Distribution extension in Argentina and new Anura and Ophidia hosts. Check List 2010; 6(3): 447-450. http://dx.doi.org/10.15560/6.3.447.

Pojmanska T. Family Plagiorchiidae Luhe, 1901. In: Bray RA, Gibson DI, Jones A, editors. Keys to the Trematoda. Wallingford: CABI Publishing and the Natural History Museum; 2008. p. 357-360. vol. 3.
Rankin JS Jr. A review of the trematode genus Glypthelmins Stafford, 1905, with an account of the life cycle of G. quieta (Stafford, 1900) Stafford, 1905. Trans Am Microsc Soc 1944; 63(1): 30-43. http://dx.doi. org/10.2307/3223334.

Razo-Mendivil UJ, León-Règagnon V, Pérez-Ponce de León G. Monophyly and systematic position of Glypthelmins (Digenea), based on partial lsrDNA sequences and morphological evidence. Org Divers Evol 2006; 6(4): 308-320. http://dx.doi.org/10.1016/j.ode.2005.12.005.

Razo-Mendivil UJ, Pérez-Ponce de León G. Taxonomic revision of the genus Glypthelmins Stafford, 1905 (Platyhelminthes: Digenea: Plagiorchiida), parasites of anurans in the Americas. Zootaxa 2008; 1882: 1-45.

Razo-Mendivil UJ, Pérez-Ponce de León G. Testing the evolutionary and biogeographical history of Glypthelmins (Digenea: Plagiorchiida), a parasite of anurans, through a simultaneous analysis of molecular and morphological data. Mol Phylogenet Evol 2011; 59(2): 331-341. PMid:21356320. http://dx.doi.org/10.1016/j.ympev.2011.02.018.

Ruiz JM, Leão TA. Choledocystus vesicalis n. sp., parasita da vesícula biliar de Bufo marinus (L.). (Trematoda: Plagiochiidae). Mem Inst Butantan 1942; 16: 209-212.

Silvano DL, Segalla MV. Conservação de anfíbios no Brasil. Megadiversidade 2005; 1(1): 79-86.

Sullivan JJ. Redescription of Choledocystus hepaticus (Lutz, 1928) n. comb., and the status of C. linguatula (Rudolphi, 1819) (Trematoda: Plagiorchoidea). Proc Helminthol Soc Wash 1977; 44(2): 162-170.

Tkach V. Family Plagiorchiidae Luhe, 1901. In: Bray RA, Gibson DI, Jones A, editors. Keys to the Trematoda. Wallingford: CABI Publishing and the Natural History Museum; 2008. p. 357-360. vol. 3.

Travassos L, Freitas JFT, Kohn A. Trematódeos do Brasil. Mem Inst Oswaldo Cruz 1969; 67: 228-240. 